\title{
Biological Significance Of Metals Partitioned To Subcellular Fractions Within Earthworms (Aporrectodea Caliginosa)
}

\author{
Martina G. Vijver,${ }^{1,}{ }^{*}$ Cornelis A.M. van Gestel, ${ }^{1}$ Nico M. van Straalen, ${ }^{1}$ \\ Roman P. Lanno, ${ }^{2}$ and Willie J.G.M. Peijnenburg ${ }^{3}$
}

1. Institute of Ecological Science, Vrije Universiteit, De Boelelaan 1085, 1081 HV Amsterdam, The Netherlands 2. College of Ecological Science, Department of Entomology, The Ohio State University, Columbus, Ohio 43210, USA 3. Laboratory for Ecological Risk Assessment, National Institute of Public Health and the Environment, P.O. Box 1, 3720 BA Bilthoven, The Netherlands

* To whom correspondence may be addressed (vijver@cml.leidenuniv.nl)

\begin{abstract}
Metal ions in excess of metabolic requirements are potentially toxic and must be removed from the vicinity of important biological molecules to protect organisms from adverse effects. Correspondingly, metals are sequestrated in various forms, defining the accumulation pattern and the magnitude of steady-state levels reached. To investigate the subcellular fractions over which $\mathrm{Ca}, \mathrm{Mg}, \mathrm{Fe}, \mathrm{Cu}, \mathrm{Zn}, \mathrm{Cd}, \mathrm{Pb}, \mathrm{Ni}$, and $\mathrm{As}$ are distributed, earthworms (Aporrectodea caliginosa) collected from the field were analyzed by isolating metal-rich granules and tissue fragments from intracellular microsomal and cytosolic fractions (i.e., heat-stable proteins and heat-denatured proteins). The fractions showed metal-specific binding capacity. Cadmium was mainly retrieved from the protein fractions. Copper was equally distributed over the protein fraction and the fraction comprising tissue fragments, cell membranes, and intact cells. Zinc, Ca, Mg, and As were mainly found in this fraction as well. Lead, Fe, and $\mathrm{Ni}$ were mainly isolated from the granular fraction. To study accumulation kinetics in the different fractions, three experiments were conducted in which earthworms were exposed to metal-spiked soil and a soil contaminated by anthropogenic inputs and, indigenous earthworms were exposed to field soils. Although kinetics showed variation, linear uptake and steady-state types of accumulation patterns could be understood according to subcellular compartmentalization. For risk assessment purposes, subcellular distribution of metals might allow for a more precise estimate of effects than total body burden. Identification of subcellular partitioning appears useful in determining the biological significance of steady-state levels reached in animals.
\end{abstract}

\section{INTRODUCTION}

Oligochaete species show a variety of accumulation patterns for trace metals, ranging from accumulation curves reaching steady-state to linear accumulation curves in which elimination is approximately zero $[1,2]$. This results in a wide range of body metal concentrations varying in biological significance. More specifically, the biological significance of a metal concentration depends on the specific tissue in which the metal is deposited, and toxicity cannot be predicted from total metal burden in the organism [3]. Sequestration mechanisms are used by invertebrates to detoxify metals and prevent interaction with important biomolecules, include metal binding to proteins and other ligands, and storage in the inorganic matrix of granules. With biochemical techniques, Wallace and Lopez [4] developed a pragmatic method to quantify different metal sequestration forms 
on the basis of several centrifugation steps. In this procedure, an organism is separated into granular and tissue, cell membrane, and cytosolic fractions. The cytosolic fraction could be further isolated into a microsomal fraction and heatstable proteins (HSP; e.g., metallothioneins) and heat-denatured proteins (HDP; e.g., enzymes) [5]. Because of the different metal affinities of the sequestration forms, it is likely that these metal fractions all have their own specific uptake and elimination kinetics. Understanding metal compartmentalization might explain accumulation and elimination patterns in organisms. Metals retrieved from fractions in which they are loosely bound might easily be eliminated from the organism, resulting in an accumulation curve reaching steady state, whereas metals bound tightly in inert fractions are eliminated slowly or not at all, resulting in linear accumulation patterns. Differences in steady-state levels in organisms can be ascribed to the additive results of accumulation kinetics of the different internal fractions.

Metal sequestration on a subcellular level has been summarized in a recently published review [6], together with the possible consequences for accumulation patterns and toxicity. In general, it was seen that the granular fraction (including metal-rich granules) and protein fractions have the greatest effect on metal accumulation by fish and other aquatic organisms. The fractions retrieved from lysosomes, nuclei, cell membranes, tissues, and intact cells were most important for elimination. In that way, these fractions were most important for the accumulation fashion, and the magnitude of steady-state levels reached in organisms after exposure corresponds predominantly to the size of these fractions. Up to now, research on the distribution of metals over the internal fractions has been performed mainly on aquatic vertebrate (fish) and invertebrate species (shrimps, mussels, freshwater oligochaetes) [4,5]. Studies on internal compartmentalization and its consequences for terrestrial organisms are scarce. As far as we know, only Conder et al. [7] and Honeycutt et al. [8] have separated soluble and pellet fractions inside earthworms with centrifugation techniques. These studies suggested that, in the soluble cytosolic fraction, metal content increased in a linear manner during exposure, whereas in the pellet fraction, consisting of granules, tissue fragments, and cell membranes, metals reached a steady-state concentration. Dallinger and Prosi [9] fractionated heavy metals from isopod hepatopancreases and demonstrated a metal-dependent distribution over pellet and supernatant.

After exposure, organisms will invoke mechanisms to minimize interactions of metals with the receptor sites of target organs, at the same time ensuring sufficient delivery of essential metals to target organs $[3,6]$. Internal response might differ between laboratory-incubated organisms exposed to artificially metal-polluted soils and indigenous animals that are subjected to chronic exposure [10]. In this research, subcellular distributions of $\mathrm{Ca}, \mathrm{Cd}, \mathrm{Cu}, \mathrm{Pb}, \mathrm{Zn}$, $\mathrm{Mg}, \mathrm{Fe}, \mathrm{Ni}$, and $\mathrm{As}$ were determined in the terrestrial oligochaete Aporrectodea caliginosa collected from the field. It was hypothesized that subcellular metal partitioning was metal specific and that accumulation and elimination kinetics could be related to the binding of metals to certain subcellular fractions. To quantify the subcellular distribution kinetics of $\mathrm{Cd}$ and $\mathrm{Zn}$ over the different fractions mentioned above, metal concentrations in $A$. caliginosa were followed over time during exposure to $\mathrm{Cd}$ - or $\mathrm{Zn}$-spiked soils. In addition, an experiment was performed in which $A$. caliginosa was incubated in the laboratory and exposed to an anthropogenically polluted field soil. To validate the laboratory observations and to investigate the differences in response between laboratoryincubated and indigenous earthworms, indigenous earthworms were exposed to field soils and, after $61 \mathrm{~d}$, transferred into their soil of origin. Our motivation to transfer worms back into their soil of origin was that we assumed that the 
Environmental Toxicology and Chemistry: No. 25, pp. 807-814.

organisms would reach their initial concentrations after the total experimental duration of $118 \mathrm{~d}$.

\section{MATERIALS AND METHODS}

\section{Experimental design}

Adult earthworms of the species $A$. caliginosa were collected from several field sites, and internal levels of $\mathrm{Cd}, \mathrm{Pb}, \mathrm{Ni}, \mathrm{Ca}, \mathrm{Cu}, \mathrm{Fe}, \mathrm{Mg}, \mathrm{Zn}$, and $\mathrm{As}$ were determined. To investigate accumulation kinetics of the subcellular fractions, three experiments were conducted.

Experiment 1. Adult earthworms of the species $A$. caliginosa were collected from a nonpolluted forest soil in Lepelstraat, The Netherlands, and kept in the laboratory for several weeks. To quantify metal accumulation kinetics of the three different subcellular fractions from which $\mathrm{Cd}$ and $\mathrm{Zn}$ were isolated, earthworms were exposed to spiked field soil and sampled at different time intervals: 4, 14, 21 , and $28 \mathrm{~d}$. Before exposure of earthworms, the field soil Epen, from The Netherlands, was spiked with a nominal concentration of $325 \mathrm{mg} \mathrm{Cd} / \mathrm{kg}$ soil and $3,100 \mathrm{mg} \mathrm{Zn} / \mathrm{kg}$ soil as metal acetate salts (purity 96\%, Acros Chemicals, Leicestershire, UK). Ten weeks after spiking, dissolved organic carbon levels in pore water stabilized, and this was used as an indication that the metal spike was in pseudoequilibrium conditions in the soil.

Experiment 2. Adult earthworms of the species $A$. caliginosa were collected from a nonpolluted sandy grassland soil in Boxtel, The Netherlands, and kept in the laboratory for several weeks. Earthworms were sampled at different time intervals: 0, 6, 13, 19, 28, and $35 \mathrm{~d}$. Cadmium, $\mathrm{Pb}, \mathrm{Ni}, \mathrm{Ca}, \mathrm{Cu}$, and $\mathrm{Zn}$ levels were analyzed in three subcellular compartments in the earthworms.

Experiment 3. Experiments with field soils and indigenous, mature earthworms were conducted to identify internal fractions from which the highest levels of metals could be isolated and to determine whether initial Cd concentrations can be reached again. For this purpose, two bioassays were conducted with $A$. caliginosa collected from two different sites: a soil from the Afferdensche en Deestsche Waarde (ADW), a floodplain of the river Waal in the middle of The Netherlands, and the field soil Epen used in spiking experiment 1. In these experiments, the worms from ADW were incubated in Epen soil and after $61 \mathrm{~d}$ transferred back into ADW soil for $57 \mathrm{~d}$, and the reverse experiment was carried out as well. Earthworms were sampled at different time intervals: 0, 1, 3, $8,13,26,42,61,63,68,92$, and $118 \mathrm{~d}$. Cadmium levels were determined from five subcellular compartments in the earthworms.

All experiments were conducted in glass jars $(750 \mathrm{ml})$, with $400 \mathrm{~g}$ of moist soil and four earthworms in each jar. All soils were kept at a moisture content of $80 \pm$ $4 \%$ of their maximum water holding capacity. After collecting the earthworms, they were placed on moist filter paper for $48 \mathrm{~h}$ to void their gut contents and then frozen at $-18^{\circ} \mathrm{C}$. The experiments were performed in a climate room at $80 \%$ relative humidity, $15 \pm 3^{\circ} \mathrm{C}$, and permanent illumination.

Before metal analyses, soil samples were dried at $40^{\circ} \mathrm{C}$ and sieved $(<2 \mathrm{~mm})$, followed by digestion in a concentrated $\mathrm{HNO}_{3}$ solution (70\% pro-analyzed JT Baker, Deventer, The Netherlands) with a Mars5 destruction microwave oven (CEM, Matthews, NC, USA). Total metal concentrations were analyzed by inductively coupled plasma-mass spectrometry (ICP-MS) with a Perkin-Elmer SciEx ELAN 6000 (Bodensee, Germany). Organic matter and carbonate content 
Environmental Toxicology and Chemistry: No. 25, pp. 807-814.

were determined by loss-on-ignition at 550 and $900^{\circ} \mathrm{C}$, respectively. Pore water was collected with a permeable pore-water sampler (Rhizon SMS-MOM, Rhizosphere Research, Wageningen, The Netherlands).

\section{Fractionation of earthworms}

Individual earthworms were thawed and homogenized with an Omni TH115 tissue homogenizer fitted with a 7-mm sawtooth blade in $5 \mathrm{ml}$ of ice-cold $0.01 \mathrm{M}$ Tris- $\mathrm{HCl}$ buffer ( $\mathrm{pH} 7.5$; Fisher Scientific, Houston, TX, USA). Homogenates were centrifuged at $10,000 \mathrm{~g}$ for $30 \mathrm{~min}$ at $5^{\circ} \mathrm{C}$. Pellet fractions were boiled at $100^{\circ} \mathrm{C}$ for $2 \mathrm{~min}$ and hydrolyzed at 60 to $70^{\circ} \mathrm{C}$ for $1 \mathrm{~h}$ with $1 \mathrm{M} \mathrm{NaOH}$ (Merck, Darmstadt, Germany). The granules (fraction D) could be separated from tissue fragments, cell membranes, and intact cells (fraction E) by centrifugation (MSE $16 \times 10$ rotor) at $10,000 \mathrm{~g}$ for $10 \mathrm{~min}$. Initial supernatants and cytosol (fraction C) were decanted, and the microsomal fraction (fraction F) was separated from the protein fraction by centrifugation (Phagus $10 \times 10$ rotor) at $100,000 \mathrm{~g}$ for 30 min. The protein fraction was heated for $10 \mathrm{~min}$ at $80^{\circ} \mathrm{C}$ and placed on ice for 1 $\mathrm{h}$. The samples were then centrifuged at $30,000 \mathrm{~g}$ for $30 \mathrm{~min}$ to separate denatured proteins (fraction $\mathrm{G}$ ) from heat-stable proteins (fraction $\mathrm{H}$ ). All supernatants were evaporated and all fractions were digested with $\mathrm{HNO}_{3}$ [4]. For analyses, the dry residues were dissolved in $0.7 \mathrm{M} \mathrm{HNO}_{3}$ (ultrapure; SigmaAldrich, Seelze, Germany). Metal quantification was performed on an atomic absorption spectrophotometer (Perkin-Elmer 1100B) with flame and graphite furnace capabilities and analyzed by ICP-MS (Perkin-Elmer, SciEx ELAN 6000). Blanks were included and standard additions were within range $(15 \%)$, indicating good recovery in the matrix.

\section{Calculations}

Data on internal metal concentrations were modeled by a nonlinear onecompartment model. Uptake rate constants and elimination rate constants of individual observations in time were fitted to the first-order equation (Eqn. 1), $Q(t)=C_{0} e^{-k_{2} t}+\frac{a}{k_{2}} \cdot 1-e^{-k_{2} t}$ metal concentration in earthworms $\left(\mu \mathrm{g} / \mathrm{g}\right.$ wet wt) at time $t(\mathrm{~d}) ; C_{0}$ is the initial concentration in earthworms $(\mu \mathrm{g} / \mathrm{g}$ wet $\mathrm{wt}) ; k_{2}$ is the elimination rate constant (per day); and $a$ is the uptake flux, modeled as $k_{1} C_{\text {extern, }}$ in which $k_{1}$ is the uptake rate constant ( $\mathrm{g} \mathrm{soil} / \mathrm{g}$ animal/d) and $C_{\text {extern }}$ is the metal concentration either in soil $(\mathrm{mg} / \mathrm{kg})$ or in pore water $(\mu \mathrm{g} / \mathrm{L})$. Each subcellular compartment was treated as an entity because, after metal entrance in the organism, metals will immediately partition over the different subcellular fractions, of which we assume the dynamics are independent of each other. Modeling and parameter quantification was done with Graphpad Prism ${ }^{\mathrm{TM}} 2.0$ (Graphpad Software, San Diego, CA, USA).

\section{RESULTS AND DISCUSSION}

\section{Subcellular metal distribution}

A qualitative generalized overall impression of $\mathrm{Cd}, \mathrm{Zn}, \mathrm{Ca}, \mathrm{Cu}, \mathrm{Pb}, \mathrm{Mg}, \mathrm{Fe}, \mathrm{Ni}$, and As (by ICP-MS) distribution over the subcellular fractions in earthworms ( $n=$ 138) collected from the field is given in Figure 1 . The percentage (\%) is calculated by relating the metal concentration retrieved from the fraction concerned to the total metal concentration in the animal. 

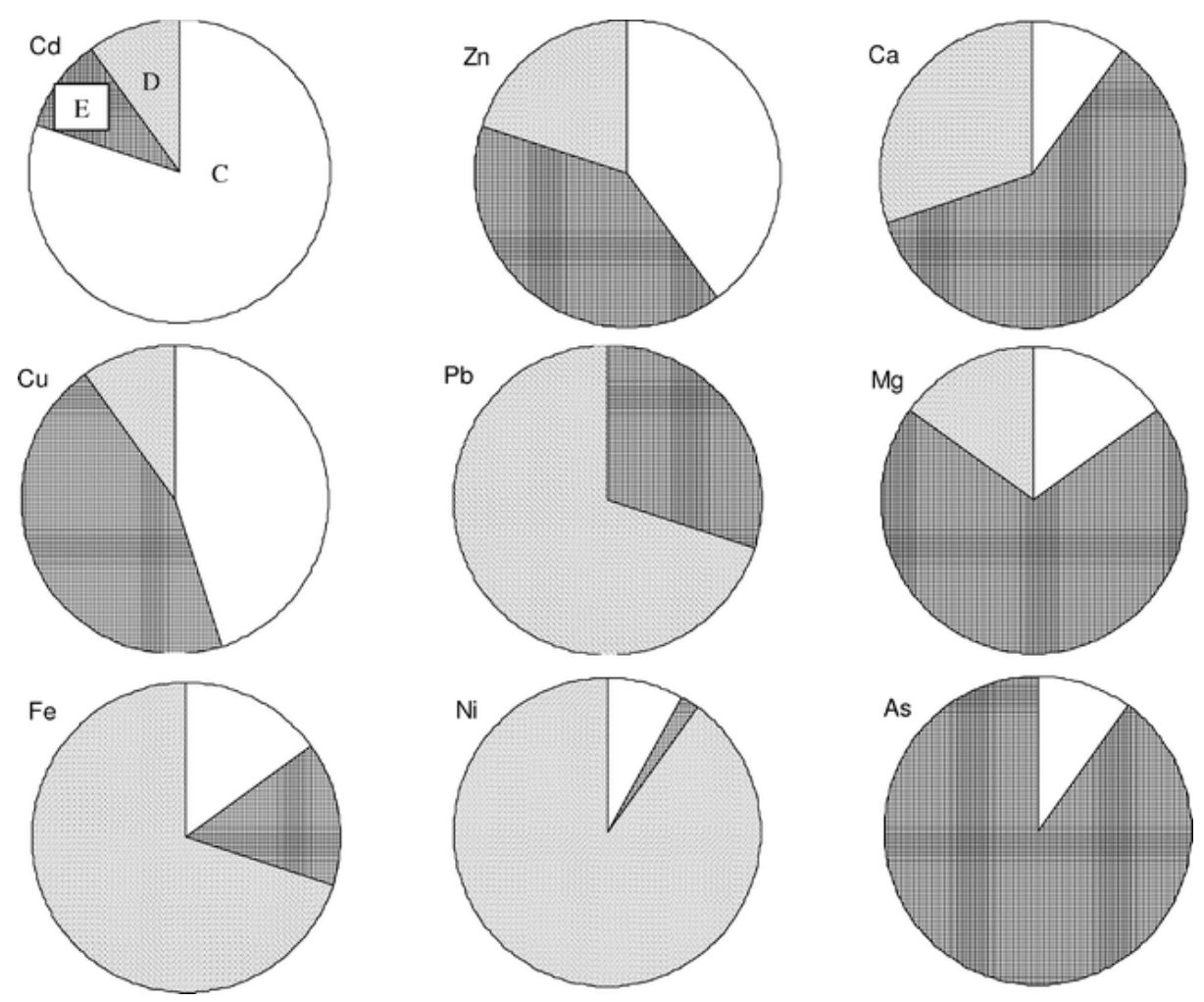

Fig. 1. Overall patterns of metal distribution and the relative percentage of metals retrieved from the different fractions in the earthworm Aporrectodea caliginosa $(n=138)$ collected from the field. D (dotted) is the granular fraction; $\mathrm{E}$ (grid) is the tissue, cell membranes, and intact cell fraction; $C$ (white) is the cytosolic fraction, including $\mathrm{F}, \mathrm{G}$, and $\mathrm{H}$ fractions (= microsomal and heatdenatured protein [HDP] and heat-stable protein [HSP] fractions)

Metal-specific differences exist in the distribution over the internal fractions that can be explained in conformance with preferred biochemical binding and physiological use of the metals by animals. In general, essential metals are present at higher levels in the tissue fragment and cell membrane fraction (E), which can be attributed to their metabolic requirements. To buffer reactive free metal cations, many metabolic processes are known to sequester metals. The processes all play a role in the maintenance of essential metals. Reactive nonessential cations are also sequestered to decrease toxic stress [3]. The binding affinity does explain many of our findings on the subcellular distribution of metals in earthworms. As seen in Figure $1, \mathrm{Ca}, \mathrm{Mg}$, and $\mathrm{Zn}$ could mainly be found in the tissue and cell membrane fraction (E). Zinc occurs in mitochondria and in proteins (e.g., zinc fingers) and is distributed over the whole body. Calcium is required for the structure of the exoskeleton, muscle contraction, and blood clotting, for example. Magnesium is a component essential to enzyme mediation [11]. Although As has no essential function, this metalloid was retrieved from the $\mathrm{E}$ fraction and from the cytosolic fraction (C) in a minor amount. Arsenate imitates phosphate, which explains the occurrence of As in the phospholipids that are part of the cell membrane. The presence of As in the cytosolic fraction is in agreement with findings from the literature showing that As is mainly bound to $S$ in glutathione [12]. Copper was equally distributed over the cytosolic fraction and the cell membrane, tissue, and intact cell fraction (E). The presence of $\mathrm{Cu}$ in the $\mathrm{E}$ fraction can be explained by its essential role in metabolism and its occurrence in the cytosolic fraction (C) by its role in the catalysis of glutathione activities and superoxide dismutase to prevent organisms from adverse effects induced by 
reactive oxygen. Contrary to $\mathrm{Cu}, \mathrm{Cd}$ was mainly found in the cytosolic fraction (C), which can be explained by heat-stable protein induction that prevents $\mathrm{Cd}$ from competing with essential metals on the $\mathrm{SH}$ sites of proteins and cysteine [13]. Cadmium, $\mathrm{Zn}, \mathrm{Ca}$, and $\mathrm{Mg}$ are partly found in the granular fraction, consisting of type $A$ granules [14] that are rich in calcium and phosphorus, with $\mathrm{Ca}$ and $\mathrm{P}$ preferably bind these oxygen-seeking cations. The nonessential metals $\mathrm{Pb}$ and $\mathrm{Ni}$ were mainly found in the granular fraction (D) disposed with sulfur (present in cysteine breakdown products), the so-called type B granules [13]. Lead and $\mathrm{Ni}$ can also be packed in lysosomes originating from the endoplasmic reticulum [11]. Nickel is known to have no clear binding preferences according to Nieboer and Richardson [15] and therefore forms ligands with many functional groups in fish; for instance, Ni was found in the microsomal fraction including lysosomes [16]. Iron was found in the granular fraction (D), described by Hopkin et al. [14] as type $C$ granules consisting of ferritin, and in equal portions in the cytosolic fraction (C) and the tissue and cell membrane fraction (E). Iron is part of the transport protein ferritin that is concentrated in granules (for isopods, known as type $C$ granules [14]). Because of its essential role in the binding of oxygen in earthworms, Fe occurs in the cytosolic and metabolically required $\mathrm{E}$ fraction.

\section{Soil properties}

Actual total metal concentrations in the metal-spiked Epen soil were $582 \mathrm{mg}$ $\mathrm{Cd} / \mathrm{kg}$ dry soil and $4,020 \mathrm{mg} \mathrm{Zn/kg}$ dry soil. Pore-water metal concentrations in this soil were $1,794 \mu \mathrm{g} \mathrm{Cd} / \mathrm{L}$ and $10.29 \mathrm{mg} \mathrm{Zn/L}$. Soil characteristics and metal concentrations in soil and pore water of the field soils are shown in Table 1. Keeping the soils at $80 \%$ of their water holding capacity corresponded to a moisture content of $41.8 \%$ wet weight for Epen (experiments 1, 3), 39.0\% wet weight for ADW (experiment 3), and $34.6 \%$ for Boxtel (experiment 2). 
Environmental Toxicology and Chemistry: No. 25, pp. 807-814.

Table 1. Physical/chemical characteristics and total and pore-water ( $\mathrm{pw}$ ) metal concentrations ( \pm standard deviation) of the field soils used in the three experimental designs. Dissolved organic carbon (DOC), the major anion, and macroelements Ca and Mg and cation concentrations are given

\begin{tabular}{|c|c|c|c|c|c|c|c|c|c|c|c|}
\hline \multirow[b]{2}{*}{ Soil } & \multirow[b]{2}{*}{ Texture } & \multicolumn{7}{|c|}{ Metal concentration $(\mathrm{mg} / \mathrm{kg}$ dry $w \mathrm{t})$} & \multirow[b]{2}{*}{$\mathrm{pH}_{\mathrm{CICl} 12}$} & \multirow{2}{*}{$\begin{array}{l}\mathrm{LOI}_{1}^{\mathrm{a}} \\
(\%)\end{array}$} & \multirow{2}{*}{$\begin{array}{l}\mathrm{LOI}_{2}^{\mathrm{b}} \\
(\%)\end{array}$} \\
\hline & & [Ca] & {$[\mathrm{Pb}]$} & {$[\mathrm{Cd}]$} & {$[\mathrm{Zn}]$} & {$[\mathrm{Cu}]$} & {$[\mathrm{Ni}]$} & {$[\mathrm{Cr}]$} & & & \\
\hline Epen & $\begin{array}{l}\text { Riverband, light clay } \\
\text { soil, humic }\end{array}$ & $2,550 \pm 71$ & $88.1 \pm 0.71$ & $2.14 \pm 0.01$ & $252 \pm 2.83$ & $13.3 \pm 0.07$ & $14.3 \pm 0.0$ & $36.5 \pm 0.14$ & $6.5 \pm 0.1$ & 8.6 & 0.56 \\
\hline Boxtel & $\begin{array}{l}\text { Riverbank, sandy soil, } \\
\text { humic }\end{array}$ & $950 \pm 71$ & $34.8 \pm 1.06$ & $2.04 \pm 0.08$ & $97.5 \pm 3.54$ & $11.3 \pm 0.14$ & $6.20 \pm 0.28$ & $25.4 \pm 0.0$ & $4.6 \pm 01$ & 5.3 & 0.16 \\
\hline \multirow[t]{2}{*}{$\mathrm{ADW}^{c}$} & $\begin{array}{l}\text { Floodplain, sandy-clay } \\
\text { soil }\end{array}$ & $27,850 \pm 495$ & $127 \pm 6.58$ & $3.65 \pm 0.20$ & $476 \pm 19.1$ & $57.2 \pm 1.41$ & $35.9 \pm 1.41$ & $95.8 \pm 4.18$ & $6.8 \pm 0$ & 6.7 & \\
\hline & $\begin{array}{l}{[\mathrm{Ca}]_{p w}} \\
(\mathrm{mg} / \mathrm{L})\end{array}$ & $\begin{array}{l}{[\mathrm{Mg}]_{\mathrm{pw}}} \\
(\mathrm{mg} / \mathrm{L})\end{array}$ & $\begin{array}{l}{[\mathrm{Pb}]_{\text {pw }}} \\
(\mu \mathrm{g} / \mathrm{L})\end{array}$ & $\begin{array}{l}{[\mathrm{Cu}]_{p w}} \\
(\mu \mathrm{g} / \mathrm{L})\end{array}$ & $\begin{array}{l}{[\mathrm{Cd}]_{p w}} \\
(\mu \mathrm{g} / \mathrm{L})\end{array}$ & $\begin{array}{l}{[\mathrm{Zn}]_{\mathrm{pw}}} \\
(\mu \mathrm{g} / \mathrm{L})\end{array}$ & $\mathrm{pH}_{\mathrm{pw}}$ & $\begin{array}{l}{ }_{\left(\mu l^{-}\right]_{p w}} \\
(\mu \mathrm{g} / \mathrm{L})\end{array}$ & $\begin{array}{c}{\left[\mathrm{NO}_{4}^{-}\right]_{\mathrm{pw}}} \\
(\mu \mathrm{g} / \mathrm{L})\end{array}$ & $\begin{array}{c}{\left[\mathrm{SO}_{4}^{2-}\right]_{p w}} \\
(\mu \mathrm{g} / \mathrm{L})\end{array}$ & $\begin{array}{c}\mathrm{DOC} \\
(\mathrm{mg} / \mathrm{L})\end{array}$ \\
\hline Epen & $71.4 \pm 27.1$ & $16.5 \pm 3.33$ & $2.43 \pm 1.11$ & $7.56 \pm 0.83$ & $7.35 \pm 2.44$ & $1,018 \pm 5.66$ & 6.8 & $15 \pm 1.3$ & $269 \pm 2.12$ & $29.0 \pm 0.0$ & 23.0 \\
\hline Boxtel & $75.7 \pm 15.4$ & $8.42 \pm 1.61$ & $1.44 \pm 0.13$ & $12.1 \pm 1.44$ & $24.0 \pm 3.48$ & $1,838 \pm 388$ & 5.1 & $47 \pm 4.2$ & $170 \pm 58.0$ & $113 \pm 1.41$ & 19.2 \\
\hline ADW & $181 \pm 25.6$ & $9.41 \pm 1.28$ & $0.32 \pm 0.08$ & $21.1 \pm 2.73$ & $1.82 \pm 0.68$ & $72.0 \pm 15.7$ & 7.2 & $25 \pm 1.4$ & $325 \pm 20.5$ & $60.5 \pm 0.71$ & 25.0 \\
\hline
\end{tabular}

${ }^{\mathrm{a}} \mathrm{LOI}_{1}=$ loss on ignition at $550^{\circ} \mathrm{C}(\%$ organic matter $)$.

${ }^{b} \mathrm{LOI}_{2}=$ loss on ignition at $900^{\circ} \mathrm{C}(\%$ inorganic matter $)$

¿Afferdensche en Deestsche Waarde (The Netherlands). 


\section{Organism performance}

No mortality of earthworms was observed in the bioassay (experimental series 1) with the Cd-and $\mathrm{Zn}$-spiked field soils. Wet weight loss was negligible over $28 \mathrm{~d}$ of exposure: differences in wet weight before and after the experiment ranged between 17 and $27 \%$. No mortality of earthworms exposed in experiment 2 was found; however, wet weights decreased $38 \%$ over time. Mortality of earthworms exposed in field soils (experimental series 3 ) was negligible and did not differ between treatments. Wet weights of $A$. caliginosa did not change over the first 61 $\mathrm{d}$ of exposure. The average wet weight $(\mathrm{mg}, \pm$ standard deviation [SD]) of earthworms sampled and sacrificed for metal analyses from the second half of the experiments were, after gut clearance: ADW-Epen-ADW, $220 \pm 130(n=18)$ and Epen-ADW-Epen, $255 \pm 110(n=16)$, which are 48 and $50 \%$ of the initial weights, respectively. Most likely, differences in soil properties caused the change in wet weight of the earthworms.

\section{Experiment 1: Turnover kinetics of subcellular Cd and Zn in earthworms exposed to spiked soil}

From the biochemical distribution of metals over the different fractions, elimination possibilities can be derived. Aporrectodea caliginosa were exposed for $28 \mathrm{~d}$ to field soil Epen, spiked with $\mathrm{Cd}$-acetate and $\mathrm{Zn}$-acetate. Initial total $\mathrm{Cd}$ concentrations in the earthworms were $4.08 \pm 1.30 \mu \mathrm{g} / \mathrm{g}$ wet weight $(n=11)$ and initial $\mathrm{Zn}$ levels were $164.4 \pm 148.2 \mu \mathrm{g} / \mathrm{g}$ wet weight $(n=10)$. During exposure of earthworms to the metal-spiked field soil, internal metal levels increased with time. The accumulation pattern of $\mathrm{Cd}$ and $\mathrm{Zn}$ over the different internal fractions-granular fraction (D); tissue, cell membrane, and intact cell fraction (E); and cytosolic fraction including proteins and microsomal fraction (C) -is shown in Figure 2. Total metal levels were calculated by summing metal concentrations of the individual subcellular fractions. Accumulation kinetics were described over time with a one-compartment model (see Eqn. 1), and uptake and elimination rate constants were quantified. Accumulation parameters and $k_{1}$ and $k_{2}$ values of the different subcellular fractions, as well as the statistics of the model fit, are given in Table 2.

Table 2. Parameters estimates ( \pm standard error $[\mathrm{SE}]$ ) for uptake and elimination kinetics of $\mathrm{Cd}$ and $\mathrm{Zn}$ in the different subcellular fractions in Aporrectodea caliginosa over $28 \mathrm{~d}$ exposure to spiked field soil (Eqn. 1, text). The uptake flux $a$ is used to calculate the uptake rate constant $k_{\mathrm{i}}$ on the basis of total metal concentrations in pore water (pw) and soil (tot) and the elimination rate constant $k_{2} ; C_{0}$ is the initial concentration

\begin{tabular}{|c|c|c|c|c|}
\hline Parameter & $\mathrm{D}$ & $\mathbf{E}$ & C & Total \\
\hline \multicolumn{5}{|l|}{$\mathrm{Cd}$} \\
\hline $\begin{array}{l}C_{Q}(\mu g / g \text { wet wt) } \\
k_{2}(\text { per day) } \\
a \\
k_{1}(\mathrm{pw})(\mathrm{ml} / \mathrm{g} \text { animal/d) } \\
k_{1 \text { too }}(\mathrm{g} \text { soil/g animal/d) } \\
r^{2}\end{array}$ & $0.73 \pm 0.18$ & $\begin{array}{l}0.63 \pm 3.52 \\
0.42 \pm 0.96 \\
2.51 \pm 5.50 \\
1.40 \times 10^{-3} \\
4.31 \times 10^{-3} \\
0.47\end{array}$ & $\begin{array}{c}2.60 \pm 7.28 \\
0.23 \pm 0.33 \\
4.44 \pm 5.90 \\
2.47 \times 10^{-3} \\
7.63 \times 10^{-3} \\
0.66\end{array}$ & $\begin{array}{l}3.49 \pm 8.11 \\
0.27 \pm 0.29 \\
6.95 \pm 7.16 \\
3.87 \times 10^{-3} \\
1.19 \times 10^{-2} \\
0.74\end{array}$ \\
\hline $\mathrm{Zn}$ & $\mathrm{D}^{\mathrm{a}}$ & $E^{b}$ & & \\
\hline $\begin{array}{l}C_{b}(\mu g / g \text { wet wt) } \\
k_{2} \text { (per day) } \\
a \\
k_{1}(\mathrm{pw})(\mathrm{mg} / \mathrm{g} \text { animal/d) } \\
k_{1 \text { gon })}(\mathrm{g} / \mathrm{g} \text { animal/d) } \\
r^{2}\end{array}$ & $\begin{array}{c}10.1 \pm 15.5 \\
0.00 \\
2.91 \times 10^{-3} \\
2.83 \times 10^{-3} \\
7.23 \times 10^{-3} \\
0.9\end{array}$ & $41.0 \pm 19.7$ & $\begin{array}{c}29.1 \pm 18.8 \\
0.11 \pm 0.08 \\
16.7 \pm 9.43 \\
1.62 \times 10^{-3} \\
4.15 \times 10^{-3} \\
0.93\end{array}$ & $\begin{aligned} & 100.0 \pm 52.3 \\
& 0.01 \pm 0.08 \\
& 8.41 \pm 15.1 \\
& 8.17 \times 10^{-4} \\
& 2.09 \times 10^{-3} \\
& 0.64\end{aligned}$ \\
\hline
\end{tabular}

Internal concentration in this fraction best modeled according to $Q=$ constant.

"Modeled best as a linear model in which $k_{2}$ is zero. 

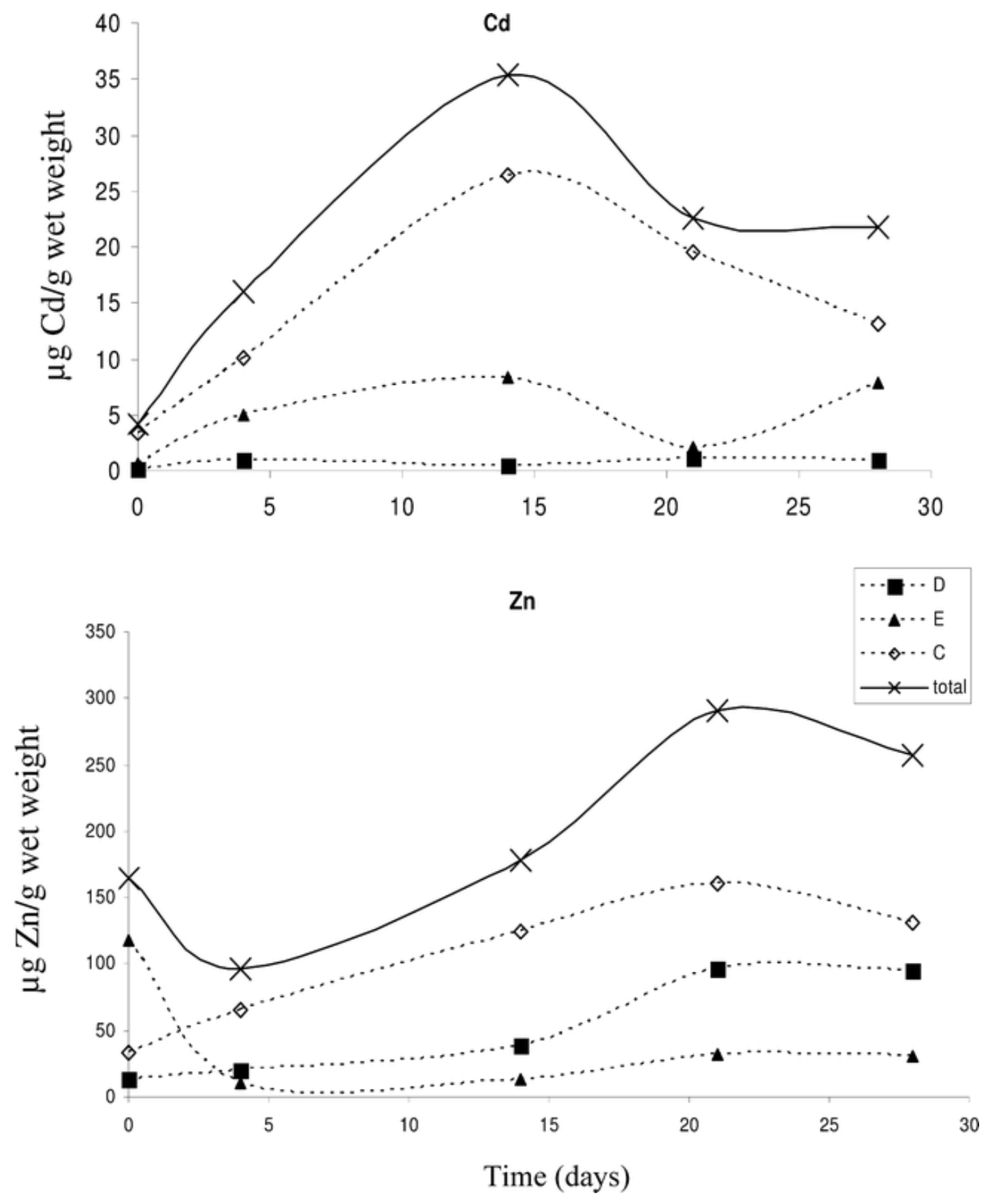

Fig. 2. Subcellular distribution of $\mathrm{Cd}$ (upper) and $\mathrm{Zn}$ (below) in the earthworm Aporrectodea caliginosa during $28 \mathrm{~d}$ of exposure to a Cd- Zn (acetate) spiked field soil. $D=$ granular fraction; $E=$ tissue, cell membrane, and intact cell fraction; $\mathrm{C}=$ the cytosolic fraction consisting of microsomal and protein fractions; total $=$ the total body concentrations obtained by summing all subcellular fractions 
Environmental Toxicology and Chemistry: No. 25, pp. 807-814.

As can be seen from Figure 2, most Cd could be retrieved from the cytosolic fraction (C), which increased over exposure time. Cadmium in fraction $\mathrm{C}$ qualitatively contributes most to $\mathrm{Cd}$ accumulation and, in a quantitative sense, the major part of Cd uptake kinetics (influx $=4.44 \mu \mathrm{g} / \mathrm{g}$ wet wt) could be explained from the cytosolic (C) fraction. Cadmium levels in the tissue fragment, cell membrane, and intact cell fraction $(E)$ also increased over time (influx $=2.51$ $\mu \mathrm{g} / \mathrm{g} \mathrm{g}$ wet $\mathrm{wt}$ ). Cadmium concentrations detected in the granular fraction (D) remained at a fixed concentration. The internal partitioning of $\mathrm{Cd}$ is in agreement with findings of Conder et al. [7], who distinguished the cytosolic fraction (C) from the pellet fraction (defined as the $D+E$ fractions in our experiment) in the earthworm Eisenia fetida exposed to Cd-spiked soil. In the case of E. fetida, the cytosolic fraction could be fitted to a linear regression model with a slope of approximately 0.3 . This linear increase of the cytosolic fraction could be explained by the extremely high Cd concentration spiked to artificial soil. The pellet fraction was modeled according to a saturation type 1 compartment model [7]. In both studies, and in the study of Honeycutt et al. [8], it was seen that for Cd, the cytosolic fraction (C) responds to the exposure concentration, whereas the pellet fraction ( $D+E$ fractions in our case) responds according to a steady-state accumulation model. Zinc concentrations showed a different response than $\mathrm{Cd}$ in the earthworms on exposure to spiked soil (Fig. 2). Zinc was mainly retrieved from the cytosolic (C) and granular (D) fractions, followed by the tissue, cell membrane, and intact cell fraction (E). The latter fraction had a high initial concentration that more or less remained on a fixed level during exposure. Zinc kinetics (Table 2) in the cytosolic fraction (C) were largest (both uptake and elimination; influx $=16.7 \mu \mathrm{g} / \mathrm{g}$ wet wt and $k_{2}=0.11$ per day) compared with the kinetics of the $D$ and $E$ fractions. Zinc in the granular fraction (D) had an elimination rate of zero. Comparing total accumulation kinetics of $\mathrm{Cd}$ and $\mathrm{Zn}$ showed that uptake rates do not differ much from each other (total influxes $=7$ $\mu \mathrm{g} \mathrm{Cd} / \mathrm{g}$ and $8 \mu \mathrm{g} \mathrm{Zn} / \mathrm{g}$, respectively), whereas the total elimination rate constant was larger for $\mathrm{Cd}$ ( 0.27 per day) than for Zn (0.01 per day).

\section{Experiment 2: Subcellular distribution over time of $\mathrm{Cd}, \mathrm{Pb}, \mathrm{Ni}, \mathrm{Ca}, \mathrm{Cu}$, and $\mathrm{Zn}$ in earthworms exposed to field soil}

Metal patterns in time in earthworms exposed to field soil Boxtel differed between metals (see Fig. 3) and could be described according to linear uptake (in which elimination rates were zero), saturation type curves, and internal levels that did not change significantly during the whole exposure duration.

The subcellular distribution of $\mathrm{Cd}, \mathrm{Ni}, \mathrm{Pb}$, and $\mathrm{Ca}$ is in good agreement with the findings in field worms (Fig. 1). Copper was almost equally distributed over granular (D) and tissue fragments, cell membrane, and intact cell fractions (E) in earthworms exposed to field soil Boxtel, whereas the relative percentage of $\mathrm{Cu}$ in the granular fraction of field worms was lower. Nevertheless, the results are in agreement with each other, and the higher $\mathrm{Cu}$ accumulation in the granular fraction can be ascribed to the relatively high $\mathrm{Cu}$ level in the pore water, together with the low pH of the Boxtel field soil (see Table 1). Zinc concentrations showed a slight difference in subcellular distribution among earthworms exposed to Boxtel soil (Fig. 3) and animals collected from the field (Fig. 1), which can be explained by the relatively low $\mathrm{Zn}$ body burden in the earthworms exposed to Boxtel. The differences can be explained from the kinetic parameter estimates for each subcellular fraction. In Table 3, an overview is given on the accumulation types and estimated parameters of the granular fraction (D), the tissue fragments and cell membrane fractions (E), and the cytosolic fractions (C) for each metal species. 
Environmental Toxicology and Chemistry: No. 25, pp. 807-814.
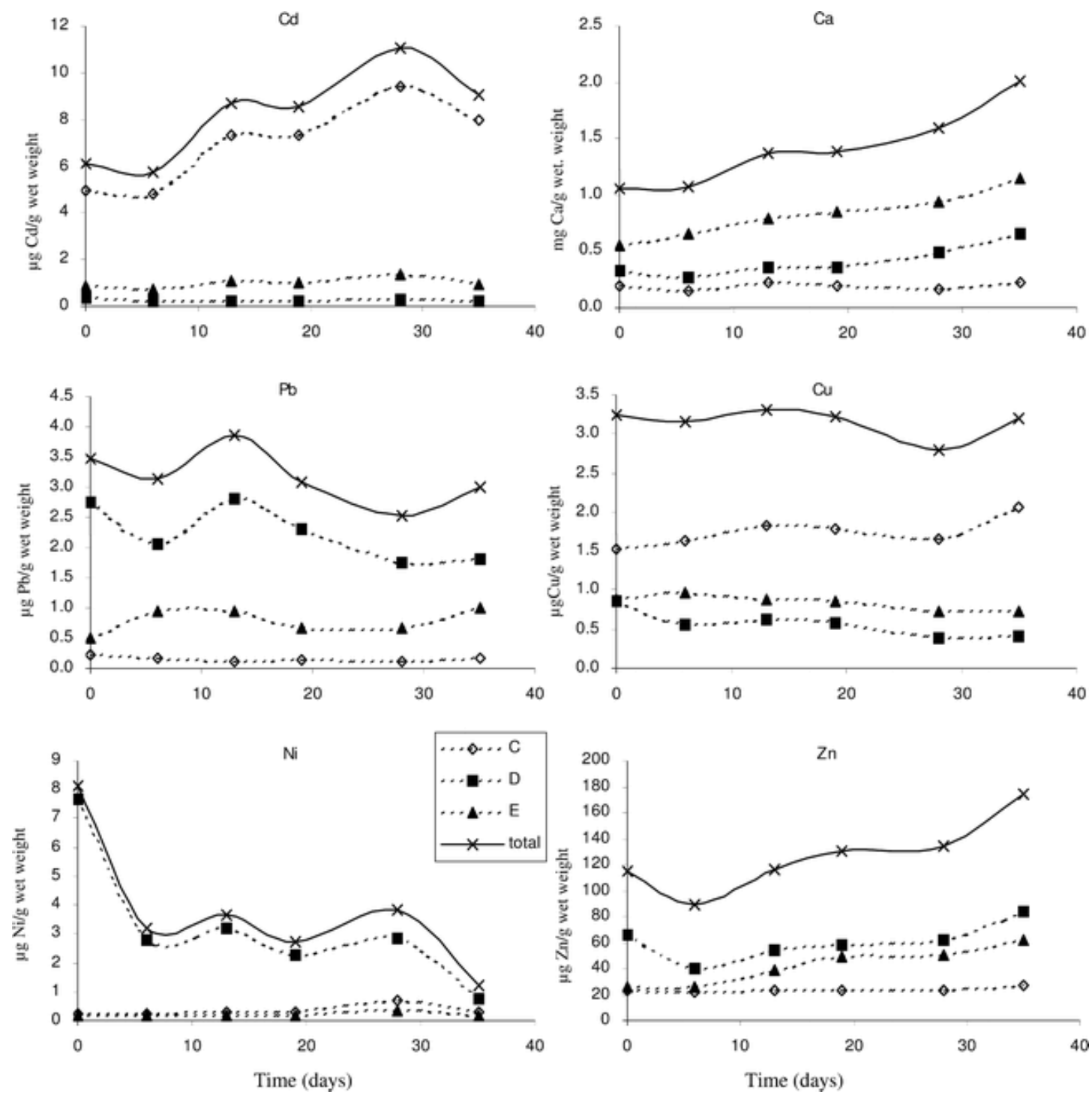

Fig. 3. Subcellular distribution of $\mathrm{Cd}, \mathrm{Pb}, \mathrm{Ni}, \mathrm{Ca}, \mathrm{Cu}$, and $\mathrm{Zn}(\mu \mathrm{g} / \mathrm{g}$ wet wt, except for $\mathrm{Ca}$ in $\mathrm{mg} / \mathrm{g}$ wet $\mathrm{wt}$ ) in the earthworm Aporrectodea caliginosa during $35 \mathrm{~d}$ of exposure to a field soil. $\mathrm{D}=$ granular fraction; $\mathrm{E}=$ tissue, cell membrane, and intact cell fraction; $\mathrm{C}=$ the cytosolic fraction consisting of microsomal and protein fractions; total = the total body concentrations obtained by summing all subcellular fractions 
Table 3. Type of accumulation pattern and parameter estimates ( \pm standard error [SE]) for $\mathrm{Cd}, \mathrm{Pb}, \mathrm{Ni}, \mathrm{Ca}, \mathrm{Cu}$, and $\mathrm{Zn}$ concentrations in the different subcellular fractions of Aporrectodea caliginosa over $35 \mathrm{~d}$ exposure to field soil (Eqn. 1).The uptake flux is $a$ (flux per kg animal) and elimination rate constant is $k_{2}$ (per day); $C_{0}$ is the initial concentration ( $\mu \mathrm{g} / \mathrm{g}$ wet wt). The $\mathrm{D}, \mathrm{E}$, and total fractions of $\mathrm{Pb}$ and $\mathrm{D}$ and total fractions for Ni did not give a significant model outcome in the models used

\begin{tabular}{|c|c|c|}
\hline $\begin{array}{l}\text { Type of } \\
\text { accumulation } \\
\text { pattern }\end{array}$ & $\begin{array}{l}\text { Metal } \\
\text { species }\end{array}$ & Fraction kinetics, and notes \\
\hline Constant & $\begin{array}{l}\mathrm{Cd} \\
\mathrm{Ca} \\
\mathrm{Pb} \\
\mathrm{Cu} \\
\mathrm{Ni} \\
\mathrm{Zn}\end{array}$ & $\begin{array}{l}\mathrm{D}, \mathrm{E} \text { fraction } \\
\mathrm{C} \text { fraction } \\
\mathrm{C} \text { fraction } \\
\mathrm{D}, \overline{\mathrm{E}}, \mathrm{C} \text {, total fraction } \\
\mathrm{E}, \mathrm{C} \text { fraction } \\
\text { C fraction }\end{array}$ \\
\hline Stcady state & $\mathrm{Cd}$ & $\begin{array}{l}\text { C fraction, } r^{2}=0.80 \\
C_{0}=4.54 \pm 0.96, k_{2}=0.04 \pm 0.06, a=0.43 \pm 0.44 \\
\text { Total fraction, } r^{2}=0.74 \\
C_{0}=5.6 \pm 1.22, k_{2}=0.05 \pm 0.07, a=0.51 \pm 0.63 \\
D \text { fraction, } r^{2}=0.69 \\
C_{0}=53.8 \pm 6.11, k_{2}=0.18 \pm 0.20, a=9.64 \pm 11.5\end{array}$ \\
\hline Linear uptake & $\mathrm{Zn}$ & $\begin{array}{l}\text { E fraction, } r^{2}=0.94 \\
C_{0}=24.3 \pm 2.89, a=1.06 \pm 0.14 \\
\text { Total fraction, } r^{2}=0.73 \\
C_{0}=95.8 \pm 11.6, a=1.83 \pm 0.56 \\
D \text { fraction, } r^{2}=0.82 \\
C_{0}=0.24 \pm 0.05, a=0.01 \pm 0.002 \\
\text { E fraction, } r^{2}=0.98 \\
C_{0}=0.56 \pm 0.03, a=0.02 \pm 0.001 \\
\text { Total fraction, } r^{2}=0.93 \\
C_{0}=0.98 \pm 0.08, a=0.03 \pm 0.004\end{array}$ \\
\hline
\end{tabular}

Cadmium accumulation in earthworms exposed to Boxtel field soil and accumulation characteristics of the subcellular fractions (Table 3 ) are in agreement with the findings on $\mathrm{Cd}$ accumulation in animals exposed to spiked Epen soil (Table 2). The only difference can be found in the amount of Cd retrieved from the tissue, cell membrane, and intact cell fraction (E) that remained on a fixed level in earthworms exposed to the Boxtel soil and showed a steady-state curve in earthworms exposed to spiked soil. The difference in metal amounts in the $\mathrm{E}$ and $\mathrm{C}$ fractions between the two experimental series can again be explained by the exposure concentrations.

The total ( $D+C+E$ fractions) accumulation pattern of $\mathrm{Zn}$ in earthworms exposed to Boxtel soil was described by linear uptake (Fig. 3), whereas Zn accumulation of earthworms exposed to spiked Epen soil followed a steady-state type of curve (Fig. 2). When comparing the subcellular fractions, it can be seen that in both cases, Zn concentrations in the $E$ fraction varied between 45 and 55 $\mu \mathrm{g} \mathrm{Zn/g}$ wet weight, whereas $\mathrm{Zn}$ level in the granular fraction (D) was in both cases equal to $75 \mu \mathrm{g} / \mathrm{g}$ wet weight. As a result, the only internal metal compartment in earthworms that varied between the two experimental series is the cytosolic fraction, which contained up to $100 \mu \mathrm{g} \mathrm{Zn/g}$ wet weight for earthworms exposed to spiked Epen soil, and $20 \mu \mathrm{g} \mathrm{Zn/g}$ wet weight for animals in Boxtel soil. Zinc uptake in Boxtel soil is linear because the metabolically 
Environmental Toxicology and Chemistry: No. 25, pp. 807-814.

required $\mathrm{Zn}$ pool (reflected in the $\mathrm{E}$ fraction) and its buffer compartment (the granular fraction, D) are both not on a level that is likely to cause overspill. Therefore, the cytosolic fraction is not yet initiated by the animal to sequester metals, which is different from the animals exposed to spiked Epen soil, in which exposure concentrations were higher compared with the Boxtel soil, and more internal detoxification is required to prevent the adverse effects caused by reactive metals taken up by the animal. Total ( $D+C=E$ fraction) $\mathrm{Zn}$ concentration in earthworms exposed to spiked Epen soil was around $220 \mu \mathrm{g} / \mathrm{g}$ wet weight and, for earthworms exposed to Boxtel field soil, around $150 \mu \mathrm{g} / \mathrm{g}$ wet weight.

In some cases, as seen in Table 3, none of the accumulation models fits the data. This happened with $\mathrm{Pb}$ and $\mathrm{Ni}$, for which modeling with a nonfixed exposure concentration will likely give a significant fit. However, we did not measure exposure concentrations as a function of time.

\section{Experiment 3: Subcellular distribution of $\mathrm{Cd}$ in indigenous earthworms exposed to soil}

Accumulation results of earthworms originating from ADW soil exposed to Epen soil (until $61 \mathrm{~d}$ ) and back into ADW soil (up to $118 \mathrm{~d}$ ) and the reverse experiment of earthworms from Epen exposed to ADW soil and back into Epen soil are depicted in Figure 4.

Cadmium levels in the different subcellular fractions showed a high degree of variation. Separation of the cytosolic fraction $(C)$ into microsomal $(F)$ and protein $(G, H)$ fractions seemed to explain parts of this variation. The Cd distribution over the different subcellular fractions was in agreement with the results found in animals in experiments 1 and 2, in which the highest Cd levels were found in the cytosolic fraction (C). A general accumulation pattern in the indigenous earthworms (Fig. 4) was difficult to obtain. During exposure, only slight changes were seen. Remarkably, earthworms incubated in Epen soil and transferred back to ADW soil had elevated Cd concentrations in the second half of the experiment, especially reflected by the subcellular protein fractions HDP $(G)$ and HSP $(H)$. Similar increases of internal Cd levels were not detected in the first half of the reverse experiment (Epen-ADW-Epen), which is basically the same experiment. This suggests that earthworms probably react in a physiological way (e.g., by inducing stress proteins) to the change in incubation and exposure conditions.

Our expectation was that organisms, after exposure to a certain field soil and transfer back to their soil of origin, ultimately would reach their initial concentrations. This expectation holds for worms originating from Epen that had initial concentrations similar to internal Cd concentrations after $118 \mathrm{~d}$ of exposure; however, no significant accumulation was seen during the entire exposure period. Cadmium levels in earthworms originating from ADW did not return to initial concentrations. This indicates that stress of organisms can influence uptake and elimination kinetics, although no strong evidence was obtained from the experimental data (Fig. 4). It should be concluded that the experimental design with reverse exposure regimes was maybe too complicated. We dealt not only with many stress interferences together with metal stress, but also the use of indigenous earthworms caused a lot of scatter in the accumulation data. One of the main reasons is that wet weights of the earthworms at the start of experiments already varied largely, although all earthworms were mature. From the literature, it is known that earthworms under stressful environmental conditions mature at lower weights to speed up the ability to reproduce [17]. A visible check for adulthood before the start of the experiment might therefore not 
be sufficient to reduce such variations in metal concentrations. In this stage of research, the use of laboratory-incubated earthworms would shed more light on the biochemical and physiological mechanisms underlying subcellular distribution of metals in animals.
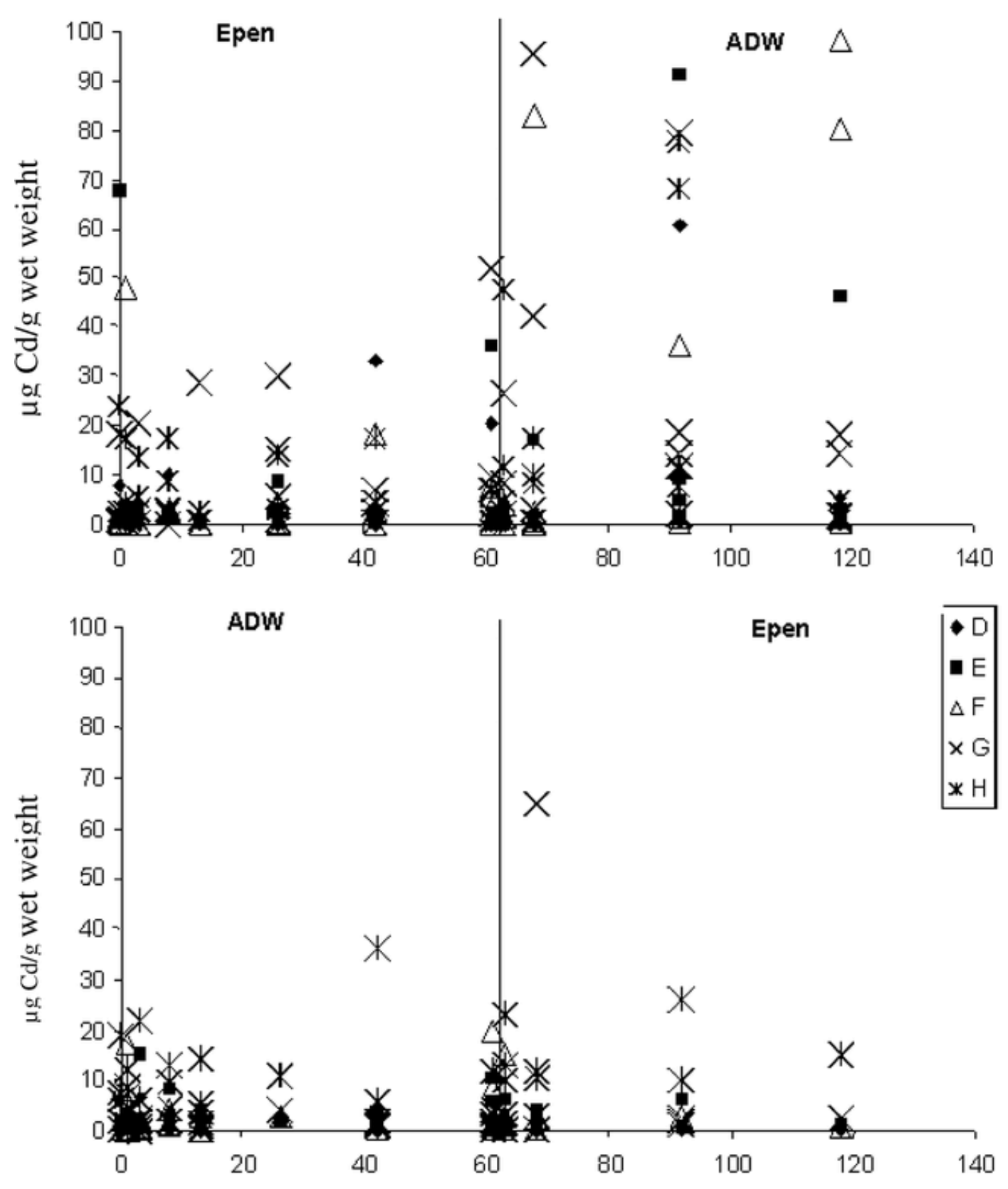

Time (days)

Fig. 4. The subcellular distribution of $\mathrm{Cd}$ over time in the earthworm Aporrectodea caliginosa incubated in soil for $61 \mathrm{~d}$ and returned to its own soil for another $57 \mathrm{~d}$, together with the reverse experiment. $\mathrm{D}=$ granular fraction; $E=$ tissue, cell membrane, and intact cell fraction; $F=$ microsomal fraction; $G=$ heat-denatured protein fraction; $\mathrm{H}=$ heat-stable protein fraction 


\section{Implications for environmental risk assessment}

To assess the effects of chemicals on organisms, often critical body residues (CBR) derived from laboratory experiments $[18,19]$ are compared with metal accumulation levels measured in organisms from the field [20]. One of the assumptions of the CBR concept is that metals accumulated in the organism are in equilibrium over the entire body. With this assumption, the capacity of organisms to sequester metals in forms that are not biologically reactive is neglected. Nevertheless, all detoxification mechanisms indicate that metal tolerance in invertebrates is realized by preventing metals from circulating freely. Within organisms, many different ways of metal sequestration can be found. This biochemical sequestration of metals can be generalized over all organisms, including earthworms in this study, but also marine mussels and shrimps [21] and fish [16]. Understanding the partitioning of accumulated metals can have an applicable pragmatic function in environmental risk assessment.

To investigate which fraction can be associated with toxicity requires more research. For most metals in earthworms, granular and cytosolic fractions (see Fig. 1) were responsible for metal immobilization, and the metals in tissue fragments, cell membrane, and intact cell fractions were mostly incorporated in the metabolically required pools. Knowledge on internal metal distribution in organisms might increase the predictive power of the CBR concept to estimate effect levels. The internal metal fractions that are in equilibrium with the reactive metal pool are responsible for the release of metals and the maintenance of a free metal pool, and thereby contribute to toxic pressure. In the same way as metal speciation in soil, the free reactive metal in the body that is likely to cause adverse effects can only be a small fraction of the total metal body burden.

\section{Acknowledgments}

We thank Serge Rotteveel (Rijksinstituut voor Integraal Zoetwaterbeheer en Afvalwaterbehandeling, Lelystad [RIZA]), Joyce ten Hove (Vrije Universiteit, Amsterdam) and Arthur de Groot (RijksInstituut voor Volksgezondheid en Milieu, Bilthoven [RIVM]) for their assistance in the experimental work. We thank the RIZA department Informatie en Meettechnologie and the RIVM department Laboratorium voor Analytische for carrying out parts of the analyses. 


\section{References}

1. Peijnenburg WJGM, Baerselman R, De Groot AC, Jager T, Posthuma L, Van Veen RPM. 1999. Relating environmental availability to bioavailability: Soil-type-dependent metal accumulation in the oligochaete Eisenia andrei. Ecotoxicol Environ Saf. 44:294-310.

2. Marinussen MPJC, Van der Zee SEATM, De Haan FAM, Bouwman LM, Hefting M. 1997. Heavy metal (copper, lead, and zinc) accumulation and excretion by the earthworm, Dendrobaena veneta. J Environ Qual. 26:278-284.

3. Rainbow PS. 2002. Trace metal concentrations in aquatic invertebrates: Why and so what?. Environ Pollut. 120:497-507.

4. Wallace WG, Lopez GR. 1996. Relationship between subcellular cadmium distribution in prey and cadmium trophic transfer to a predator. Estuaries. 19:923-930.

5. Wallace WG, Luoma SN. 2003. Subcellular compartmentalization of Cd and $\mathrm{Zn}$ in two bivalves. II. Significance of trophically available metal (TAM). Mar Ecol Prog Ser. 257:125-137.

6. Vijver MG, Van Gestel CAM, Lanno RP, Van Straalen NM, Peijnenburg WJGM. 2004. Internal metal sequestration and its ecotoxicological relevance-A review. Environ Sci Technol. 38:4705-4712.

7. Conder JM, Seals LD, Lanno RP. 2002. Method for determining toxicologically relevant cadmium residues in the earthworm Eisenia fetida. Chemosphere. 49:1-7.

8. Honeycutt ME, Roberts BL, Roane DS. 1995. Cadmium disposition in the earthworm Eisenia fetida. Ecotoxicol Environ Saf. 30:143-150.

9. Dallinger R, Prosi F. 1988. Heavy metals in terrestrial isopod Porcellio scaber Latr. II. Subcellular fractionation of metal accumulating lysosomes from hepatopancreas. Cell Biol Toxicol. 4:97-109.

10. Giguere A, Couillard Y, Campbell PGC, Perceval O, Hare L, Pinel-Alloul B, Pellerin J. 2003. Steadystate distribution of metals among metallothionein and other cytosolic ligands and links to cytotoxicity in bivalves living along a polymetallic gradient. Aquat Toxicol. 64:185-200.

11. Avila VL. 1995. Biology, Investigating Life on Earth, 2nd ed. Jones and Bartlett, Boston, MA, USA.

12. Langdon CJ, Piearce TG, Feldmann J, Semple KT, Meharg AA. 2003. Arsenic speciation in the earthworms Lumbricus rubellus and Dendrodrilus rubidus. Environ Toxicol Chem. 22:1302-1308.

13. Stürzenbaum SR, Kille P, Morgan AJ. 1998. The identification, cloning and characterization of earthworm metallothionein. FEBS Lett. 431:437-442.

14. Hopkin SP, Hames CAC, Dray A. 1989. X-ray microanalytical mapping of the intracellular distribution of pollutant metals. Microsc Anal. 1:23-27.

15. Nieboer E, Richardson DHS. 1990. The replacement of the nodescript term 'heavy metals' by a biologically and chemically significant classification of metal ions. Environ Pollut (Ser B). 1:3-26.

16. Giguère A, Campbell PGC, Hare L, McDonald DG, Rasmussen JB. 2004. Influence of lake chemistry and fish age on cadmium, copper, and zinc concentrations in various organs of indigenous yellow perch (Perca flavescens). Can J Fish Aquat Sci. 61:1702-1716.

17. Zorn MI. 2004. The floodplain upside down: Interactions between earthworm bioturbation, flooding, and pollution. PhD thesis. Vrije Universiteit, Amsterdam, The Netherlands.

18. McCarty LS, Mackay D. 1993. Enhancing ecotoxicological modeling and assessment. Environ Sci Technol. 27:1719-1727.

19. Lanno RP, LeBlanc SC, Knight BL, Tymowski R, Fitzgerald DG. 1998. Application of body residues as tool in the assessment of soil toxicity. In Sheppard SC, Bembridge JD, Holmstrup M, Posthuma L, eds, Advances in Earthworm Ecotoxicology. SETAC, Pensacola, FL, USA, pp 41-52.

20. Van Straalen NM. 1996. Critical body concentrations: Their use in bioindication. In Van Straalen NM, Krivolutsky DA, eds, Bioindicator Systems for Soil Pollution. Kluwer, Dordrecht, The Netherlands, pp 5-16.

21. Wallace WG, Lee B-G, Luoma SN. 2003. Subcellular compartmentalization of Cd and Zn in two bivalves. I. Significance of metal-sensitive fractions (MSF) and biologically detoxified metal (BDM). Mar Ecol Prog Ser. 249:183-197. 